\title{
PERAN PROTEIN PILI 11 kDa Streptococcus pneumoniae SEBAGAI PROTEIN HEMAGLUTININ DAN ADHESIN
}

\section{Role of Pili Protein 11 kDa of Streptococcus pneumoniae as Hemagglutinin and Adhesin Protein}

\author{
Diana Chusna Mufida ${ }^{1 \star}$, Yuna Annisa Salsabila ${ }^{2}$, Enny Suswati ${ }^{1}$, Bagus \\ Hermansyah $^{3}$, Dini Agustina ${ }^{1}$ \\ ${ }^{1}$ Departemen Mikrobiologi, Fakultas Kedokteran Universitas Jember, \\ ${ }^{2}$ Program Studi Fakultas Kedokteran Universitas Jember, \\ ${ }^{3}$ Departemen Parasitologi, Fakultas Kedokteran Universitas Jember, \\ Jl. Kalimantan No.37, Kampus Tegal Boto, Kabupaten Jember, Jawa Timur, 68121, Indonesia \\ *Email: chusna.fk@unej.ac.id
}

\begin{abstract}
Streptococcus pneumoniae has pili which play roles in adhesion, colonization of nasopharyngeal epithelial cells, and phagocytic inhibition of immune cells. This study aimed to determine the characteristics of the $11 \mathrm{kDa}$ pili protein as hemagglutinin and adhesin, as well as their immune responses. The $11 \mathrm{kDa}$ pili protein from S. pneumoniae was isolated by SDS-PAGE, purified by electroelution and dialysis. Hemagglutination and adhesion tests were carried out on the protein, and western blotting of the polyclonal antibody immune responses were evaluated. Hemagglutination test showed that the $11 \mathrm{kDa}$ pili protein played a role in the hemagglutination process up to 2-time dilution. Adhesion test showed there was a correlation between the dose of the protein and the bacteria attached to the epithelial cells. The Pearson correlation test showed a $P$ value of 0.010 and a correlation coefficient of $R=-90.919$. Quadratic regression test produced $R^{2}=0.974$. Western blotting test showed that $11 \mathrm{kDa}$ pili protein polyclonal antibodies recognized $67 \mathrm{kDa}$ and $11 \mathrm{kDa}$ pili proteins. The study concluded that the $11 \mathrm{kDa}$ S. pneumoniae pili protein acted as hemagglutinin and adhesin, and the polyclonal antibody protein responded to $67 \mathrm{pDa}$ and $11 \mathrm{kDa} B M$ pili proteins.
\end{abstract}

Keywords: adhesin, hemagglutinin, pili, protein $11 \mathrm{kDa}$, Streptococcus pneumoniae

\begin{abstract}
ABSTRAK
Streptococcus pneumoniae memiliki pili yang berperan dalam adhesi, kolonisasi sel epitel nasofaring, serta sebagai inhibitor fagositosis sel imun. Penelitian ini bertujuan mengetahui karakteristik protein pili $11 \mathrm{kDa}$ sebagai hemagglutinin dan adhesin serta respons imunnya. Protein pili $11 \mathrm{kDa}$ dari bakteri S. pneumoniae diisolasi secara SDS-PAGE, dipurifikasi dengan elektroelusi dan dialysis. Uji hemaglutinasi dan adhesi dilakukan pada protein tersebut, serta dievaluasi respon imun poliklonal antibodinya secara western blotting. Uji hemaglutinasi menunjukkan protein pili 11 $\mathrm{kDa}$ berperan dalam proses hemaglutinasi hingga pengenceran 2 kali. Uji adhesi menunjukkan korelasi antara dosis protein dan bakteri yang menempel pada sel epitel. Uji korelasi Pearson menunjukkan P value 0,010 dan koefisien korelasi $R=-0,919$. Uji regresi Quadratic menghasilkan $\mathrm{R}^{2}=0,974$. Uji Western blotting menunjukkan antibodi poliklonal protein pili $11 \mathrm{kDa}$ mengenali protein pili $67 \mathrm{kDa}$ dan $11 \mathrm{kDa}$. Penelitian ini berkesimpulan protein pili $11 \mathrm{kDa}$ S. pneumoniae berperan sebagai hemaglutinin dan adhesin, serta antibodi poliklonal protein tersebut memberi respons terhadap protein pili BM $67 \mathrm{kDa}$ dan $11 \mathrm{kDa}$.
\end{abstract}

Kata Kunci: adhesin, hemaglutinin, pili, protein $11 \mathrm{kDa}$, Streptococcus pneumoniae 


\section{PENDAHULUAN}

Streptococcus pneumoniae termasuk dalam genus Streptococcus, famili Streptococceae. Bakteri ini berkoloni utamanya pada traktus respiratorius. Karakteristik yang dimiliki $S$. pneumoniae antara lain: diplococcus, berkapsul, dan fakultatif anaerob. Streptococcus pneumoniae dapat menyebabkan penyakit seperti pneumonia sinusitis akut, otitis media, konjungtivitis, meningitis, osteomyelitis, arthritis septik, endokarditis, peritonitis, perikarditis, selulitis, dan abses otak. Orangorang yang memiliki daya tahan tubuh rendah mudah terkena pneumonia, meningitis, dan bakterimia. Bakteri ini menjadi penyebab tertinggi Community-acquired pneumonia (CAP) sebagai penyebab utama sepsis di seluruh dunia (Feldman dan Anderson 2016).

Streptococcus pneumoniae yang berkoloni pada permukaan mukosa nasofaring inang dapat bermigrasi ke paruparu sehingga menyebabkan pneumonia pneumococcal. Infeksi ini mengakibatkan inflamasi pada kantung udara atau alveolus dengan peningkatan cairan, membuat penderita sulit untuk bernapas. Penderita yang mengalami pneumonia biasanya memiliki gejala peningkatan tekanan darah, napas pendek, batuk terus menerus, dan demam (Henriques-Normark dan Tuomanen 2013). Walaupun kolonisasi S. pneumoniae asimptomatis di nasofaring, respons imun dan clearance yang rendah dapat menyebabkan risiko serius pneumonia pneumococcal pasien defisiensi imun atau immunocompromised (Wunderink dan Waterer 2014).

Bakteri $S$. pneumoniae memiliki pili yang berfungsi sebagai promotor adhesi dan kolonisasi sel epitel nasofaring, serta inhibitor fagositosis sel imun. Kapsul polisakarida pada bakteri ini dapat menghindari mukus nasal dan neutrofil. Hal ini menyebabkan bakteri memiliki ikatan spesifik sehingga mudah melekat dengan kuat pada mukosa saluran napas, dan melakukan inisiasi faktorfaktor virulensi (Steel et al. 2013; Xu et al. 2014).

Penelitian faktor adhesin yang pernah dilakukan antara lain oleh Suharsono et al. (2014) bahwa protein pili 49,6 kDa Helicobacter pylori berperan sebagai hemaglutinin dan adhesin. Penelitian Mufida et al. (2009) menyatakan bahwa protein OMP (outer membrane protein) $55 \mathrm{kDa}$ bakteri Salmonella typhi isolat Jember sebagai protein hemaglutinin dan adhesin. Subunit protein pili $18 \mathrm{kDa}, 23 \mathrm{kDa}, 34 \mathrm{kDa}, 53 \mathrm{kDa}$ dan OMP $23 \mathrm{kDa}$ dan $27 \mathrm{kDa}$ pada bakteri Shigella flexneri penyebab shigellosis juga dilaporkan pada penelitian Fitrianingsih et al. (2017). Penelitian Milliana et al. (2017) menemukan antibodi terhadap adhesi $S$. flexneri OMP $28 \mathrm{kDa}$. Protein haemaglutinin OMP $35 \mathrm{kDa}$ juga berperan sebagai protein adhesin pada Proteus mirabilis (Suswati dan Mufida 2010). Pada penelitian Mufida et al. (2018) menyebutkan bahwa pili $S$. pneumoniae mempunyai protein dengan berat molekul $67 \mathrm{kDa}, 54 \mathrm{kDa}, 25 \mathrm{kDa}$, dan $11 \mathrm{kDa}$. Protein $54 \mathrm{kDa}$ terbukti sebagai protein hemagglutinin dan bersifat imunogenik. Protein $11 \mathrm{kDa}$ merupakan salah satu protein penyusun pili, tetapi belum diketahui fungsinya, sehingga perlu diteliti perannya dalam proses patogenesis infeksi S. pneumoniae.

Tujuan penelitian ini adalah untuk mengetahui hubungan antara titer protein pili $11 \mathrm{kDa}$ bakteri $S$. pneumoniae dengan indeks adhesi dan potensi protein pili dalam peranannya sebagai protein adhesin dan hemaglutinin. Jika dari hasil penelitian dapat dibuktikan bahwa protein tersebut merupakan protein hemaglutinin yang juga berperan dalam proses adhesi, maka protein tersebut berpotensi menjadi kandidat vaksin.

\section{BAHAN DAN METODE}

\section{Tempat dan waktu penelitian}

Penelitian dilakukan di Laboratorium Mikrobiologi Fakultas Kedokteran Universitas Jember. Waktu penelitian selama 4 bulan, dari bulan Agustus sampai dengan bulan November 2019.

\section{Bahan}

Pada penelitian ini digunakan sampel kultur S. pneumoniae yang didapatkan dari Balai Laboratorium Kesehatan (BLK) Surabaya. Penelitian ini terdiri dari beberapa tahap, tahap pertama yaitu identifikasi untuk konfirmasi spesies bakteri dan kultur untuk perbanyakan bakteri. Pada tahap ini dibutuhkan Gram staining kit, dan beberapa media seperti BAP, TCG dan BHI. Tahap kedua isolasi dan profiling protein pili dengan 
elektroforesis (SDS PAGE) dengan bahan gel elektroforesis, buffer running dan marka protein. Tahap ketiga adalah uji hemaglutinasi, uji adhesi dan Western blotting. Pada tahap ketiga menggunakan mencit jantan strain BALB/C dengan umur 68 minggu. Mencit tersebut didapatkan dari Malang dan sebelum digunakan dilakukan aklimatisasi selama 7 hari. Penggunaan hewan coba pada penelitian ini mendapat persetujuan etik dari komisi etik Fakultas Kedokteran Universitas Jember dengan nomor 1.353/H25.1.11/KE/2019.

\section{Kultur dan isolasi pili}

Bakteri S. pneumoniae dikultur pada media bifasik BHI-TCG yang diperkaya dengan 5\% darah domba. Setelah diinkubasi selama $2 \times 24$ bakteri dipanen dan ditampung pada tabung $100 \mathrm{~mL}$, ditambah TCA sampai konsentrasi $3 \%$, kemudian dikocok selama 30 menit, dibiarkan pada suhu kamar selama 1 jam, dan terakhir disentrifus pada suhu $4^{\circ} \mathrm{C}$, 6.000 rpm selama 30 menit. Endapan bakteri sebanyak $3 \mathrm{~g}$ disuspensi dengan $6 \mathrm{~mL}$ PBS $\mathrm{pH} 7,4$ kemudian diletakkan pada tabung pemotong pili. Pili dipotong dengan kecepatan 5000 rpm pada suhu $4^{\circ} \mathrm{C}$ selama 30 detik. Sampel kemudian disentrifus dengan kecepatan $12.000 \mathrm{rpm}$ selama 15 menit. Supernatan dipisahkan dan endapan diresuspensi dengan PBS pH 7,4 secukupnya, kemudian dilakukan kembali pemotongan pili. Proses ini diulang sebanyak 4 kali dan diperoleh supernatan yang mengandung protein pili serta endapan yang merupakan bagian sel bakteri (Sumarno et al. 2011; Sarkono et al. 2016).

\section{Pemisahan protein pili secara SDS-PAGE}

Berat molekul protein pili ditentukan melalui sodium dodecyl sulfatepolyacrylamide gel electrophoresis (SDSPAGE) menggunakan separating gel 12\% dan stacking gel 4\%. Sampel supernatan protein pili, sebelum dimasukkan ke dalam sumuran gel, ditambah dengan buffer yang mengandung 62,5 mM Tris- $\mathrm{HCl}(\mathrm{pH} \mathrm{6,8)}$, $10 \%$ glycerol, dan $0,001 \%$ bromophenol blue dengan 5\% (v/v) mercaptoethanol, kemudian dipanaskan selama 5 menit. Sebanyak $20 \mu \mathrm{L}$ sampel protein pili dimasukkan ke dalam sumuran gel. Elektroforesis dilakukan selama 60 menit, 125 Volt, pada suhu ruang dalam buffer elektroda $\mathrm{pH}$ 8,3. Selanjutnya dilakukan pewarnaan gel menggunakan coomassie brilliant blue selama 30 menit, dan dilanjutkan destaining dengan larutan yang mengandung $20 \%$ metanol dan $10 \%$ asam asetat glasial (Sumarno et al. 2011; Jariyapan et al. 2012).

\section{Purifikasi secara elektroelusi dan dialisis}

Gel yang mengandung pita $11 \mathrm{kDa}$ dipotong, dimasukkan ke dalam membran selulose dan ditambahkan buffer elektroda, selanjutnya dilakukan elektroforesis apparatus horizontal 125 Mv selama 120 menit. Hasil elektroelusi berupa larutan protein $11 \mathrm{kDa}$ dalam buffer elektroda dilakukan didialisis dalam $2 \mathrm{~L}$ PBS $\mathrm{pH} 7,4$ selama $2 \times 24$ jam pada suhu $4^{\circ} \mathrm{C}$ (Seelert dan Krause 2008).

\section{Uji hemaglutinasi}

Protein pili yang telah dipurifikasi berdasarkan berat molekul direaksikan dengan eritrosit mencit dan dilihat titer hemaglutinasinya. Eritrosit mencit sebelum digunakan dicuci 3 kali dengan PBS $\mathrm{pH} 7,4$ kemudian dibuat suspensi $0,5 \%$ dengan larutan PBS. Setiap sumur mikrotiter dimasukkan $50 \mu \mathrm{L}$ PBS. Sumur pertama ditambahkan $50 \mu \mathrm{L}$ protein pili kemudian dibuat pengenceran serial ke dalam sumur berikutnya dengan memipet $50 \mu \mathrm{L}$ suspensi protein pili dari sumur sebelumnya, sumur ke9 sebagai kontrol hanya diisi larutan PBS tanpa protein pili. Masing-masing ditambahkan $50 \mu \mathrm{L}$ suspensi eritrosit, kemudian digoyangkan 15 menit. Hasil hemaglutinin dibaca jika terlihat dot ( $\mathrm{Li}$ et al. 1999).

\section{Uji adhesi}

Bakteri S. pneumoniae dibiakkan dalam blood agar plates (BAP) pada suhu $37^{\circ} \mathrm{C}$ kemudian dipanen dengan mengerok bakteri dan dibuat menjadi larutan bakteri dengan menambah larutan PBS, kemudian dilakukan penentuan konsentrasi bakteri $10^{8} \mathrm{~mL}^{-1}$ menggunakan spektrofotometer pada panjang gelombang $600 \mathrm{~nm}$. Suspensi bakteri sebanyak $400 \mu \mathrm{L}$ ditambahkan pada masing-masing dosis pili. Sebelumnya protein pili $11 \mathrm{kDa}$ diencerkan dengan larutan PBS sehingga dosis protein pili menjadi 50 $\mu \mathrm{g}, 25 \mu \mathrm{g}, 12,5 \mu \mathrm{g}, 6,25 \mu \mathrm{g}$ dan 3,125 $\mu \mathrm{g}$. Kontrol negatif yang tidak terdapat protein pili juga diberikan perlakuan bakteri. Selanjutnya 
suspensi pneumosit sebanyak $400 \mu \mathrm{L}$ ditambahkan pada masing-masing dosis protein pili yang telah ditambahkan suspensi bakteri, termasuk kontrol negatif yang tidak terdapat protein pili, dan dihomogenkan. Kemudian homogenat digoyangkan perlahan menggunakan shaking waterbath pada suhu $37^{\circ} \mathrm{C}$ selama 30 menit. Setelah itu dilakukan sentrifugasi selama 5 menit, dengan kecepatan 1.000 rpm. Selanjutnya supernatan dibuang dan endapan diresuspensi dengan PBS $100 \mu \mathrm{L}$, dilakukan sentrifugasi selama 5 menit, dengan kecepatan 1.000 rpm. Setelah dilakukan pengulangan sebanyak 2 kali, endapan diresuspensi dengan $50 \mu \mathrm{L}$, masing-masing suspensi diambil sebanyak $10 \mu \mathrm{L}$ untuk dibuat preparat, selanjutnya dilakukan pewarnaan Gram (Nagayama et al. 1995; Milliana et al. 2017).

\section{Produksi poliklonal antibodi}

Produksi poliklonal antibodi dilakukan dengan menggunakan hewan coba mencit BALB/C. Protein hemaglutinin pili $11 \mathrm{kDa} S$. pneumoniae sebagai antigen diinjeksikan pada mencit secara intraperitoneal dengan dosis $50 \mu \mathrm{g}$ ditambahkan freund adjuvant complete dengan volume yang sama dengan antigen. Satu minggu kemudian dilakukan imunisasi boster (imunisasi kedua dan ketiga) menggunakan freund adjuvant incomplete dengan dosis yang sama dengan antigen. Satu minggu setelah imunisasi terakhir mencit diterminasi dan diisolasi antibodinya dari serum (Eivazi et al. 2015).

\section{Western Blotting}

Protein pada gel hasil elektroforesis SDS-PAGE ditransfer ke dalam membran Polyvinylidene difluoride (PVDF) dengan menggunakan alat semi dry blotter (Biorad). Pita protein dipindahkan pada PVDF dengan cara mengalirkan aliran listrik sebesar 100 mA pada kurun waktu 120 menit. Setelah pemindahan selesai, dilakukan pengecatan menggunakan pewarna ponco $2 \%$ yang mengandung TCA konsentrasi 30\% untuk mengetahui protein sampel telah pindah pada PVDF. Setelah itu PVDF dicuci dengan TBS 3 kali, kemudian diblok dengan skim milk 5\% dalam TBS-T dan diinkubasi 2 jam pada suhu ruang di atas shaker. Selanjutnya PVDF dicuci dengan TBST 3 kali selama 5 menit dan ditambahkan antibodi primer dalam blocking buffer perbandingan 1:20. PVDF diinkubasi semalam pada suhu $4^{\circ} \mathrm{C}$, selanjutnya membran dicuci dengan TBST 3 kali dan diinkubasi dengan antibodi sekunder 1:2.000, selama 2 jam pada suhu ruang. Membran dicuci dengan TBST 3 kali dan ditetesi dengan NBT-BCIP, kemudian diinkubasi 40 menit dalam wadah gelap. Reaksi dihentikan dengan akuades dan membran dikeringkan (Mahmood dan Yang 2012).

\section{HASIL DAN PEMBAHASAN}

Hasil SDS-PAGE menunjukkan bahwa pili tersusun oleh protein dengan berat molekul $67 \mathrm{kDa}, 54 \mathrm{kDa}, 25 \mathrm{kDa}$, dan $11 \mathrm{kDa}$ (Gambar 1). Protein pili hasil purifikasi secara elektroelusi dan dialisis dilakukan uji hemaglutinasi menggunakan erirosit mencit. Hasil uji hemaglutinasi menunjukkan protein pili menghambat aglutinasi eritrosit sampai pengenceran 2 kali (Gambar 2). Hal ini menunjukkan bahwa protein pili $11 \mathrm{kDa}$ bakteri $S$. pneumoniae dapat berperan sebagai protein hemaglutinin.

Uji adhesi dilakukan setelah uji hemaglutinin untuk melihat potensi protein pili dalam mempengaruhi proses adhesi bakteri $S$. pneumoniae ke sel pneumosit. Konsentrasi protein pili yang digunakan dalam uji adhesi yaitu 0 (kelompok kontrol), $3,125 \mu \mathrm{g}, 6,25 \mu \mathrm{g}, 12,5 \mu \mathrm{g}, 25 \mu \mathrm{g}$, dan $50 \mu \mathrm{g}$.

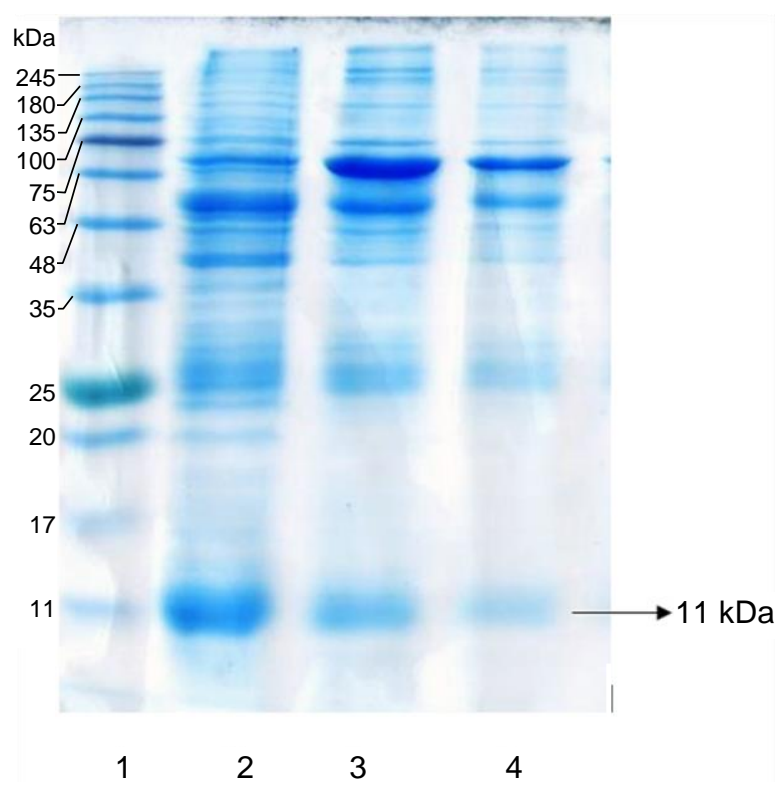

Gambar 1. Hasil elektroforesis pili $S$. pneumoniae: (1) marker, (2) whole cell, (3) pili-1, dan (4) pili-2 
Tabel 1. Indeks adhesi S. pneumoniae pada sel pneumosit mencit

\begin{tabular}{ccccccc}
\hline \multirow{2}{*}{ Sampel } & \multicolumn{7}{c}{ Dosis Protein Pili } \\
\cline { 2 - 6 } & $50 \mu \mathrm{L}$ & $25 \mu \mathrm{L}$ & $12,5 \mu \mathrm{L}$ & $6,25 \mu \mathrm{L}$ & $3,125 \mu \mathrm{L}$ & $0 \mu \mathrm{L}$ \\
\hline I & 335 & 304 & 419 & 470 & 620 & 549 \\
II & 235 & 285 & 408 & 446 & 534 & 521 \\
III & 271 & 341 & 471 & 450 & 565 & 577 \\
Rata-rata & 280 & 310 & 433 & 455 & 540 & 549 \\
\hline
\end{tabular}

Keterangan: Pengujian dilakukan dengan 3 ulangan yaitu I, II dan III

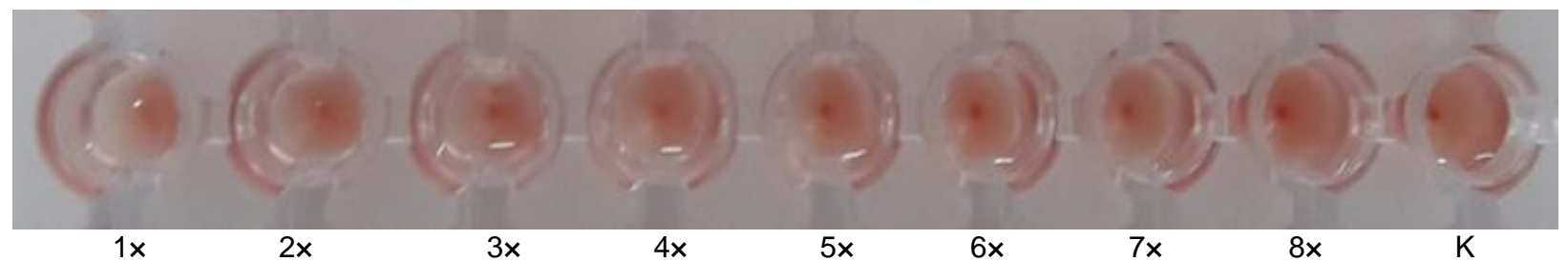

Gambar 2. Hasil uji hemaglutinin protein pili bakteri S. pneumoniae

Hasil uji adhesi menunjukkan bahwa pada kelompok kontrol terlihat lebih banyak bakteri yang menempel pada sel pneumosit. Konsentrasi protein pili $S$. pneumoniae yang semakin tinggi menyebabkan semakin sedikit bakteri S. pneumoniae yang menempel pada pneumosit. Hal ini karena reseptor pneumosit telah dijenuhi oleh protein pili sehingga bakteri tidak bisa menempel (Gambar 3 dan Tabel 1). Hasil uji korelasi Pearson menunjukkan adanya hubungan signifikan antara titer protein pili dan indeks adhesi dengan koefisien korelasi $R=-0,919$ ( $p<$ 0,05 ), membuktikan bahwa protein pili dan indeks adhesi memiliki hubungan yang kuat dengan arah yang berlawanan. Uji regresi didapatkan $R^{2}=0,974$ (Gambar 4), sehingga dapat disimpulkan terdapat $2,6 \%$ faktor lain yang mempengaruhi indeks adhesi. Contoh faktor lain yang berpengaruh dalam adhesi $S$. pneumoniae ialah suhu dan $\mathrm{pH}$. Suhu optimal adhesi $S$. pneumoniae ialah $34^{\circ} \mathrm{C}$ pada kolonisasi pernapasan bagian atas, namun pada suhu rendah menyebabkan adhesi bakteri mengalami penurunan yang signifikan (Chao et al. 2015). Kemasaman terendah yang berpengaruh terhadap jumlah adhesi $S$. pneumoniae ke sel epitel ialah $\mathrm{pH}$ 2,5 dengan rentang waktu selama 5 menit.

Hasil uji hemaglutinasi dan adhesi menunjukkan bahwa protein pili $11 \mathrm{kDa}$ merupakan protein hemagglutinin dan adhesin. Protein pili yang mempunyai sifat hemaglutinin berperan dalam proses adhesi ke sel hospes. Hasil penelitian ini didukung oleh beberapa penelitian lain, diantaranya penelitian pada bakteri Shigella menunjukkan bahwa kemampuan kolonisasi bakteri berhubungan dengan kemampuan hemaglutinasi. Semakin tinggi kemampuan hemaglutinasi semakin tinggi pula kemampuan melakukan kolonisasi (Mitra et al. 2012). Kolonisasi didahului oleh adanya adhesi, sehingga dapat disimpulkan bahwa protein hemaglutinin berperan dalam proses adhesi. Penelitian Connolly et al. (2017) menunjukkan bahwa bakteri Porphyromonas
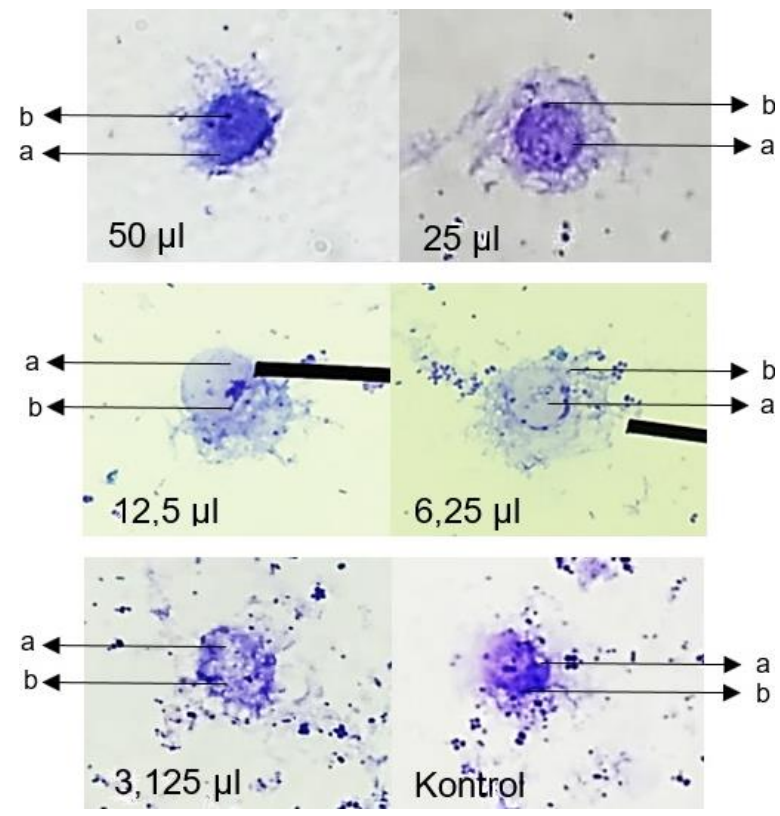

Gambar 3. Hasil uji adhesi protein pili $11 \mathrm{kDa} S$. pneumoniae dengan berbagai konsentrasi atau dosis protein pili: (a) pneumosit, (b) bakteri S. pneumoniae 
gingivalis mempunyai protein hemaglutinin pili yang berperan pada adhesi ke sel epitel mulut, kolonisasi dan pembentukan biofilm. Pada bakteri gram positif, yaitu Staphylococcus saprophyticus memiliki protein hemaglutinin yang berperan dalam proses adhesi dengan cara mengikat fibronektin ureter manusia telah dibuktikan secara in vitro, serta mempunyai peran pada kolonisasi di ginjal tikus secara in vivo, sehingga protein tersebut disebut sebagai protein adhesin (Kline dan Lewis 2016). Penelitian Suharsono et al. (2014) menyimpulkan bahwa subunit pili 49,6 kDa $H$. pylori berperan sebagai protein adhesin dan hemaglutinin. Bakteri $S$. typhi pada penelitian Sumarno et al. (2012) dengan protein pili berat molekul $48 \mathrm{kDa}$ juga berperan sebagai protein adhesin pada sel enterosit.

Protein adhesin merupakan salah satu komponen bakteri yang berfungsi melekatkan sel patogen dengan sel inang. Protein adhesin terdiri atas OMP dan pili atau fimbria.
Bakteri gram positif seperti $S$. pneumoniae memiliki pili atau fimbria dan protein permukaan sebagai protein adhesin. Setelah bakteri melakukan penempelan, sebagian kapsul polisakarida dilepaskan di tempat adhesi untuk akses bakteri ke mukosa. Hal ini memfasilitasi paparan molekul adhesive pada dinding sel atau membran sitoplasma. Reseptor pneumosit yang menjadi target adhesi bakteri $S$. pneumoniae ialah struktur glikoprotein (Binsker et al. 2015). Pneumosit tipe 2 dapat mensintesis dan mensekresi komplemen C3, menyediakan target adhesi S. pneumoniae ke sel inang melalui choline binding protein $\mathrm{A}(\mathrm{CbpA})$.

Uji Western blotting menggunakan antibodi poliklonal protein pili $11 \mathrm{kDa}$ menunjukkan bahwa antibodi tersebut memberi respons terhadap protein pili berat molekul 67 dan 11 kDa (Gambar 5). Hasil Western blotting yang mereaksikan antibodi IgG anti-protein pili $S$. pneumoniae $11 \mathrm{kDa}$ dari serum mencit yang diimunisasi protein pili 11

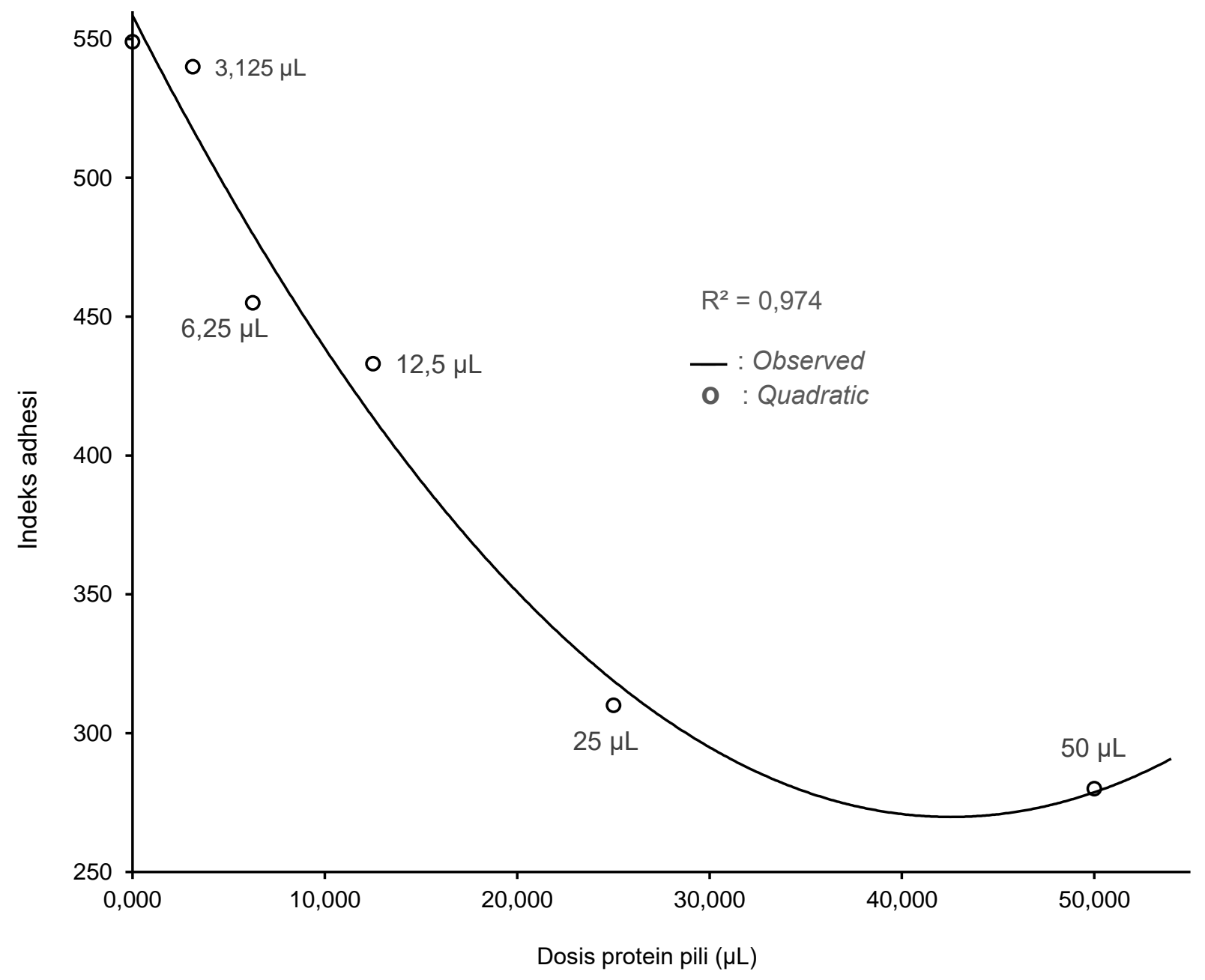

Gambar 4. Grafik analisis data regresi quadratic 
$\mathrm{kDa}$, sebagai antigen. Antibodi IgG yang diproduksi dari mencit yang diimunisasi tersebut dapat mengenali antigen protein pili $11 \mathrm{kDa}$. Protein hemaglutinin bakteri lain yang menunjukkan sifat imunogenik yaitu protein hemaglutinin fimbrial $B$. pertussis. Sifat ini ditunjukkan pada individu yang diimunisasi dengan vaksin DPT yang mengandung protein hemaglutinin fimbrial $B$. pertussis menghasilkan antibodi yang tinggi terhadap protein hemaglutinin tersebut (Hara et al. 2013).

Penelitian Fitrianingsih et al. (2017) menyatakan bahwa subunit protein pili $S$. flexneri berat molekul 18, 23, 34, 49, dan 53 $\mathrm{kDa}$ berespon terhadap antibodi subunit protein pili $18 \mathrm{kDa} S$. flexneri, serta bersifat sebagai protein hemaglutinin dan adhesin. OMP $28 \mathrm{kDa}$ bakteri $S$. flexneri sebagai protein adhesin dan hemaglutinin, antibodi OMP $28 \mathrm{kDa} S$. flexneri yang diencerkan $1 / 400$ bereaksi dengan OMP Shigella pada Western blotting (Milliana et al. 2017). Bakteri

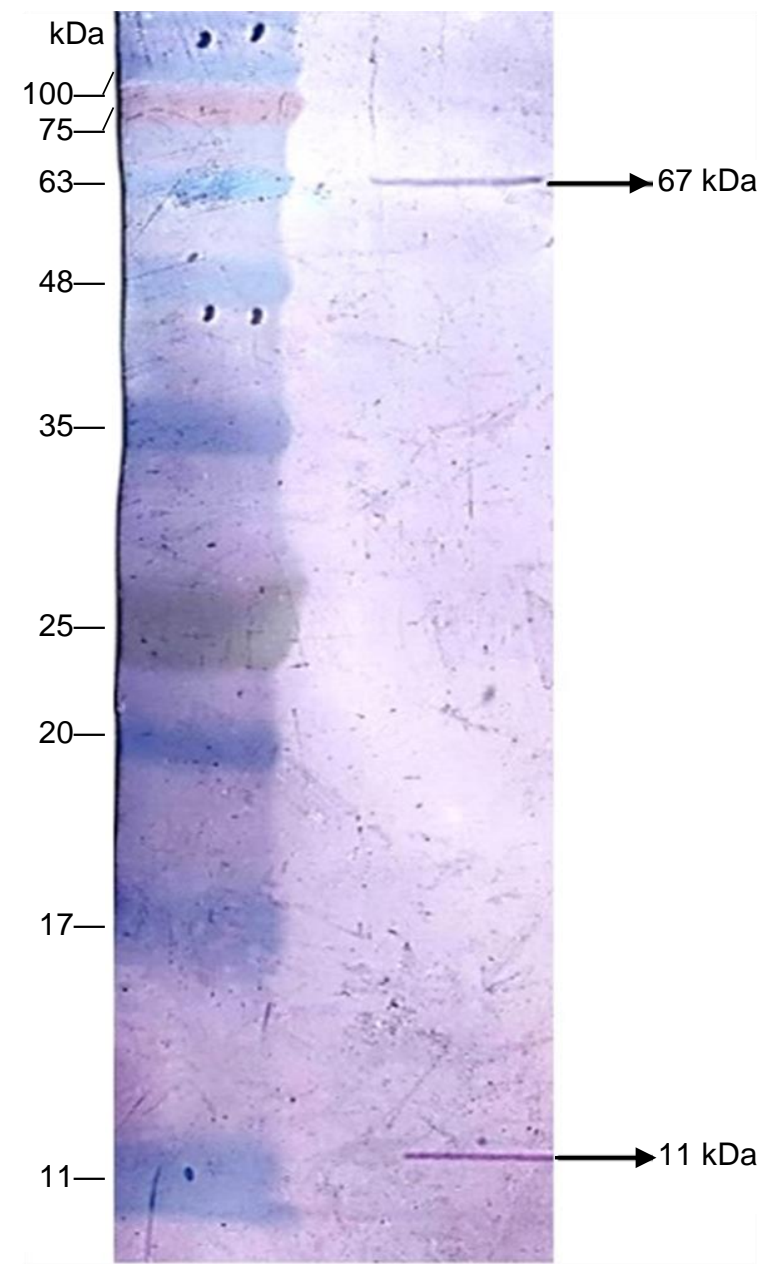

Gambar 5. Hasil Western blotting pili bakteri $S$. pneumoniae terhadap antibodi poliklonal protein $11 \mathrm{kDa}$
K. pneumoniae memiliki pili sebagai protein hemaglutinin dengan berat molekul 12,8 kDa, juga berespon terhadap antibodi Western (Agustina 2017).

Beberapa karakteristik penentu yang dapat mempengaruhi dan meningkatkan suatu zat dapat bersifat immunogen antara lain: foreignness (benda asing), ukuran molekul, struktur kimia, dan kompleksitas kimia. Benda asing dapat berupa produk mikroba dan molekul eksogen. Pada umumnya benda asing bersifat imunogenik kuat. Pada ukuran molekul, protein makromolekul merupakan immunogen yang potensial, sedangkan molekul yang lebih kecil dari $10 \mathrm{kDa}$ memiliki sifat imunogenik lemah kecuali apabila digabungkan menjadi protein karier imunogenik. Struktur kimia dari protein dan polisakarida memiliki sifat imunogenik yang kuat, walaupun rantai polipeptida kecil, asam nukleat, dan lemak dapat berpotensi imunogenik. Kompleksitas kimia dan antigenitas memiliki hubungan langsung, protein polimer atau agregasi memiliki sifat imunogenik yang lebih kuat daripada protein monomer terlarut (Andre Greiciely et al. 2017).

\section{KESIMPULAN}

Kesimpulan yang dapat diambil berdasarkan hasil penelitian ialah protein pili $11 \mathrm{kDa} S$. pneumoniae berperan sebagai protein hemaglutinin dan adhesin. Antibodi poliklonal protein pili $11 \mathrm{kDa}$ memberi respons terhadap protein pili berat molekul 67 kDa dan 11 kDa.

\section{UCAPAN TERIMA KASIH}

Ucapan terima kasih disampaikan kepada Universitas Jember melalui Hibah Keris dengan SPK No. 1334/UN25.3.1/LT 20/9 tanggal 3 Mei 2019 serta dr Cholis Abrori, M.Kes, M.Ped atas saran pengolahan data statistik dan mb Lilis Lestari selaku teknisi Laboratorium Mikrobiologi FK Unej.

\section{DAFTAR PUSTAKA}

Agustina D (2017) Deteksi imunoglobulin G dengan immunoblotting pasca imunisasi subkutan protein hemaglutinin pili Klebsiella pneumoniae $12,8 \mathrm{kDa}$ pada mencit BALB/C. J Agromed Med Sci 3:40-46. doi: 
10.19184/ams.v3i2.5069

Andre GO, Converso TR, Politano WR, Ferraz LC, Ribeiro ML, Leite LC. Darrieux M (2017) Role of Streptococcus pneumoniae proteins in evasion of complement-mediated immunity. Front Microbiol 8:224. doi: 10.3389/fmicb.2017.00224

Binsker U, Kohler TP, Krauel K, Kohler S, Schwertz H, Hammerschmidt S (2015) Pneumococcal adhesins PavB and PspC are important for the interplay with human thrombospondin-1. J Biol Chem 290:14542-14555. doi: 10.1074/jbc.M114.623876

Chao Y, Marks LR, Pettigrew MM, Hakansson AP (2015) Streptococcus pneumoniae biofilm formation and dispersion during colonization and disease. Front Cell Infect Microbiol 4:194. doi: 10.3389/fcimb.2014.00194

Connolly E, Millhouse E, Doyle R, Culshaw S, Ramage G, Moran GP (2017) The Porphyromonas gingivalis hemagglutinins $\mathrm{HagB}$ and $\mathrm{HagC}$ are major mediators of adhesion and biofilm formation. Mol Oral Microbiol 32:35-47. doi: 10.1111/omi.12151

Eivazi S, Majidi J, Maleki LA, Abdolalizadeh J, Yousefi M, Ahmadi M, Dadashi S, Moradi Z, Zolali E (2015) Production and purification of a polyclonal antibody against purified mouse lgG2b in rabbits towards designing mouse monoclonal isotyping kits. Adv Pharm Bull 5:109_ 113. doi: $10.5681 / a p b .2015 .015$

Feldman C, Anderson R (2016) The role of Streptococcus pneumoniae in community-acquired pneumonia. Semin Respir Crit Care Med 37:806818. doi: $10.1055 / \mathrm{s}-0036-1592074$

Fitrianingsih AA, Rachma LN, Milliana A, Hernowati TE, Aulanni'am A, Santoso S, Prawiro SR (2017) Cross reaction among antibody pili subunit hemagglutinin proteins and outer membrane sub unit hemagglutinin proteins of Shigella flexneri. J Trop Life Sci 7:1-7. doi: 10.11594/jtls.07.01.01

Hara M, Okada K, Yamaguchi Y, Uno S, Otsuka Y, Shimanoe C, Nanri H, Horita M, Ozaki I, Nishida Y, Tanaka K (2013) Immunogenicity and safety after booster vaccination of diphteria, tetanus, and accelular pertussis in young adults: An open randomized controlled trial in Japan. Clin Vaccine Immunol 20:1799-1804. doi: 10.1128/CVI.00490-13

Henriques-Normark B, Tuomanen El (2013) The pneumococcus: Epidemiology, microbiology, and pathogenesis. Cold Spring Harb Perspect Med 3:a010215. doi: 10.1101/cshperspect.a010215

Jariyapan N, Roytrakul S, Paemanee A, Junkum A, Saeung A, Thongsahuan S, Sor-Suwan S, Pattanawiboon B, Poovorawan Y, Choochote W (2012) Proteomic analysis of salivary glands of female Anopheles barbirostris species A2 (diptera: Culicidae) by twodimensional gel electrophoresis and mass spectrometry. Parasitol Res 111:1239-1249. doi: 10.1007/s00436012-2958-y

Kline KA, Lewis AL (2016) Gram-positive uropathogens, polymicrobial urinary tract infection, and the emerging microbiota of the urinary tract. Microbiol Spectr 4:UTI-0012-2012. doi: 10.1128/microbiolspec.UTI-0012-2012

Li X, Johnson DE, Mobley HLT (1999) Requirement of $\mathrm{MrpH}$ for mannoseresistant Proteus-like fimbriaemediated hemaglutination by Proteus mirabilis. Infect Immun 67:2822-2833

Mahmood T, Yang PC (2012) Western blot: technique, theory, and trouble shooting. N Am J Med Sci 4:429-434. doi: 10.4103/1947-2714.100998

Milliana A, Noorhamdani AS, Poeranto S, Handono K, Prawiro SR, Fitrianingsih AA, Rachma LN (2017) Antibodies against Shigella flexneri adhesion molecule outer membrane protein (OMP) can cross-react with OMPs of some Shigella species. Trop J Pharm Res 16:255-261. doi: 10.4314/tjpr.v16i2.2

Mitra S, Saha DR, Pal A, Niyogi SK, Mitra U, Koley $\mathrm{H}(2012)$ Hemaglutinating activity is directly correlated with colonization ability of Shigellae in suckling mouse model. Can J Microbiol 58:1159-1166. doi: 10.1139/w2012-095

Mufida DC, Bumi C,. Fatmawati H (2009) Peran protein membran luar $55 \mathrm{KDa}$ Salmonella typhi isolat Jember sebagai protein hemaglutinin dan adhesin. Berk Penel Hayati 15:11-16. doi: 10.23869/bphjbr.15.1.20093 
Mufida DC, Handono K, Prawiro SR, Santoso $S$ (2018) Identification of hemagglutinin protein from Streptococcus pneumoniae pili as a vaccine candidate by proteomic analysis. Turk $\mathrm{J}$ Immunol 6:8-15. doi: 10.25002/tji.2018.698

Nagayama K, Oguchi T, Arita M, Honda T (1995) Purification and characterization of a cell-associated hemagglutinin of Vibrio parahaemolyticus. Infect Immun 63:1987-1992.

Sarkono S, Moeljopawiro S, Setiaji B, Sembiring $L$ (2016) Analysis of whole cell protein profiles by SDS-PAGE to identify indigenous cellulose-producer acetic acid bacteria. Indones $\mathrm{J}$ Biotechnol 21:86-92. doi: 10.22146/ijbiotech.27166

Seelert H, Krause F (2008) Preparative isolation of protein complexes and other bioparticles by elution from polyacrylamide gels. Electrophoresis 29:2617-2636. doi: 10.1002/elps.200800061

Steel HC, Cockeran R, Anderson R, Feldman C (2013) Overview of communityacquired pneumonia and the role of inflammatory mechanisms in the immunopathogenesis of severe pneumococcal disease. Mediators Inflamm 2013:490346. doi: $10.1155 / 2013 / 490346$

Suharsono H, Hendrayana MA, Mantik IN, Prawiro SR (2014) Confirmation of adherence protein hemagglutinin subunit pili with MW $49.6 \mathrm{kDa}$ Helicobacter pylori on mice gastric epithelial cell. IOSR J Pharm Biol Sci 9:59-66. doi: 10.9790/3008-09275966

Sumarno RP, Susanto A, Ismanoe G, Wienarsih $S$ (2011) Combinations of protein sub-unit pili $37.8 \mathrm{kDa} V$. cholerae with cholera toxin sub-unit $\mathrm{B}$, $V$. cholerae can protect some out of the solution in the intestinal mice. J Pharm Biomed Sci 1:154-160

Sumarno RP, Yanuhar U, Winarsih S, Islam S, Santoso S (2012) Detection of molecule adhesion sub-unit pili $48 \mathrm{kDa}$ Salmonella typhi by immunochemistry method using sera patients suffering from typhoid fever. J Basic Appl Sci Res 2:8527-8532

Suswati E, Mufida DC (2010) Protein haemaglutinin outer membran protein (OMP) $35 \mathrm{kDa}$ sebagai protein adhesin Proteus mirabilis pada vesika urinaria kelinci. J Natur Indones 12:136-142. doi: 10.31258/jnat.12.2.136-142

Wunderink RG, Waterer GW (2014) Clinical Practice. Community-acquired pneumonia. N Engl J Med 370:543551. doi: 10.1056/NEJMcp1214869

Xu Y, Yuen PW, Lam JK (2014) Intranasal DNA vaccine for protection against respiratory infectious diseases: The delivery perspectives. Pharmaceutics 6: 378-415. doi: 10.3390/pharmaceutics6030378 